\title{
The Association of Whole Blood Viscosity with Clinical Outcomes After Mechanical Thrombectomy for Acute Ischemic Stroke
}

\section{Akut İskemik İnme İçin Mekanik Trombektomi Sonrası Klinik Sonuçlarla Tam Kan Viskozitesinin İlișkisi

\author{
Mustafa YENERÇĂ 1 (D)
}

\begin{abstract}
${ }^{1}$ Department of Cardiology, University of Health Sciences Samsun Training and Research Hospital, Samsun, TURKEY 2 Department of Neurology, University of Health Sciences Samsun Training and Research Hospital, Samsun, TURKEY

${ }^{3}$ Department of Neurology, Kartal Dr. Lütfi Kırdar Training and Research Hospital, İstanbul, TURKEY
\end{abstract}

\section{Abstract}

Background: Blood viscosity (BV) is relationship cerebrovascular events. However, the association with between BV and clinical outcomes after acute ischemic stroke (AIS) has not been studied. This study evaluated the relationship between whole blood viscosity (WBV) and clinical outcomes after AIS. Materials and Methods: The study enrolled 240 consecutive patients with AIS who underwent mechanical thrombectomy (MT) between 2017 and 2019 years. The all patients were divided according to the modified Rankin Scale (mRS) score, as good (mRS 0-2) and poor (mRS 3-6) clinical outcomes group. WBV was calculated by the formula derived from total protein and haematocrit levels.

Results: Poor clinical outcomes group presented significantly higher WBV values both at LSR and HSR ( $p$ $<0.001$ ). Multivariate analysis, both high WBV at LSR (Odd ratio: $2.679, \mathrm{p}<0.001$ ) and high WBV at HSR (Odd ratio: $1.278, p<0.001$ ) were independent predictors for poor clinical outcomes. In receiver operating characteristic analysis, value of 16.1 WBV at HSR had $76.7 \%$ sensitivity and $76 \%$ specificity for predicting poor clinical outcomes and a value of 38.5 WBV at LSR had $75.3 \%$ sensitivity and $78 \%$ specificity for predicting poor clinical outcomes. There was a significant positive correlation between WBV at LSR and mRS score $(0-6)(r=0.457, p<0.001)$ and WBV at HSR and mRS score $(0-6)(r=0.452, p<0.001)$.

Conclusions: Increased WBC may be independent risk factor and correlated with poor clinical outcomes in AIS patients treated with MT.

Key Words: Blood viscosity, Stroke, Acute, Thrombectomy

ÖZ.

Amaç: Artmış kan viskozitesi (KV) iskemik inme ile ilişkilidir. Ancak, akut iskemik inme (Aii) sonrası kan viskozitesi ve klinik sonuçlar arasındaki ilişki şu ana kadar yeterince değerlendirilmemiştir. Bu çalışmanın amacı tam kan viskozitesi (TKV) ve Ail sonrası klinik sonuçlar arasındaki ilişkiyi değerlendirmektir.

Materyal ve Metod: Çalışmaya 2017-2019 yılları arasında mekanik trombektomi (MT) yapılan 240 ardışık Aii hastası alındı. Hastalar 90. günde değerlendirilen modifiye Rankin Skalası (mRS) skoruna göre iyi klinik sonuç (mRS 0-2) ve kötü klinik sonuç (mRS 3-6) olarak iki gruba ayrıldı. TKV, hem düşük kayma hızında (DKH) hem de yüksek kayma hızında (YKH) hematokrit ve total plazma protein seviyeleri kullanılarak hesaplandı.

Bulgular: Kötü klinik sonuç grubunda TKV hem DKH' de $(34.9 \pm 0.2$ 'ye karșı $44.9 \pm 3.2 ; \mathrm{p}<0.001)$ hem de YKH'de (15.9 \pm 0.28 'e karşı $16.4 \pm 0.42 ; \mathrm{p}<0.001)$ anlamlı olarak daha yüksekti. ROC analizinde, YKH' deki 'TKV' nin 16,1'lik kesme değeri, kötü sonuçları tahmin etmek için \% 76,7 duyarlılık ve \% 76 özgüllüğe sahipti. DKH'deki TKV'nin 38,5'lik kesme değeri kötü klinik sonuçları tahmin etmek için \% 75,3 duyarlılık ve \% 78 özgüllüğe sahipti. Çok değişkenli analizde hem DKH'de hem de YKH'deki yüksek TKV değerleri, kötü sonuçlar için bağımsız prediktörler olarak saptandı. DKH'deki TKV değerleri ile mRS skoru (0-6) $(r=0.457$, $p<0.001)$ arasında, YKH'deki TKV değerleri ile mRS skoru (0-6) arasında anlamlı pozitif korelasyon vardı $(r$ $=0.452, p<0.001$ ).

Sonuç: Hem DKH de hem de YKH de artmış TKV değerleri, MT ile tedavi edilen Aii hastalarında kötü klinik sonuçlar için bağımsız risk faktörü olabilir, mRS skoru ile pozitif korelasyon gösterir.

Anahtar kelimeler: Kan viskozitesi, İnme, Akut, Trombektomi
Corresponding Author / Sorumlu Yazar

Dr. Mustafa Yenerçağ

University of Health Sciences Samsun

Training and Research Hospital,

Department of Cardiology, Baris Bulvari,

No: 199, 55400, Samsun, TURKEY

E-mail: mustafayenercag@hotmail.com

Received / Geliş Tarihi: 21.12.2020

Accepted / Kabul Tarihi: 01.03.2021

DOI: $10.35440 /$ hutfd. 843952 


\section{Introduction}

Blood viscosity (BV) is an important blood property. Blood viscosity is determined by haematocrit, plasma viscosity, red blood cells and shear rate (1). WBV can be calculated from hematocrit (Hct) and plasma total protein levels (TP) for low and high shear rates. Increased blood viscosity (BV) is relationship atherothrombotic events and in many studies with ischemic stroke (2-4).

Mechanical thrombectomy (MT) is a standard treatment for acute ischemic stroke (AIS) patients with large vessel occlusion (LVO) if they undergo the procedure within an appropriate time interval (5). Several meta-analyses showed a substantial clinical efficacy of MT in AIS (6). Despite experienced stroke teams, a good outcome is not achieved in all patients treated. Many factors can affect functional outcome after MT. However, an association between WBV and functional outcomes have not yet been studied.

In this study, the effect of WBV on clinical outcomes of AIS due to a LVO treated with MT was investigated.

\section{Materials and Methods \\ Study population}

In the present study, 240 consecutive patients with Ais who underwent MT between 2017 and 2019 who were registered in the database of Samsun Training and Research Hospital were investigated. Patients with anticoagulant drug use for any reason, acute coronary syndromes, important hypertrophy of the left ventricle, severe valvular disorders and prosthetic valve, acute decompensated heart failure, chronic infectious diseases, chronic inflammatory or autoimmune diseases, and oncologic pathologies, severe anemia, and missing data were excluded from the study. Demographical data, medical history, drugs used and laboratory values were obtained using the hospital's database. Ethics Committee of University of Health Sciences, Training and Research Hospital (TUEK1-2019 BADK /1-5).

\section{Study Procedure}

In all patients, large cerebral artery occlusions were detected on computed tomographic angiography. MT was performed in case of occlusion of LVO (middle cerebral artery, internal carotid artery, basilar artery). MT was initiated within the first 6 hours after stroke onset. MT was performed using stent retrievers. Stroke subtype was determined according to TOAST (Trial of Org 10172 in the Acute Stroke Treatment) classification. Successful recanalization was defined as modified $\mathrm{TICl}$ (Thrombolysis in Cerebral Infarction Scale) $\geq 2 \mathrm{~b}$. ICH (intracerebral hemorrhage) was evaluated computed tomography or magnetic resonance imaging after 24 hours. Neurological deficit was evaluated using the NIHSS (National Institutes of Health Stroke Scale) after 24 hours and clinical outcome after 90 days using the modified Rankin scale (mRS). The $\mathrm{mRS}$ is evaluated of patient functional independence following a stroke, with scores ranging from 0 (fully independent) to 6 (dead) (7). The mRS scoring was evaluated by a neurologist at outpatient clinic visits. The all patients were divided into two groups according to the mRS score evaluated on day 90, as good clinical outcomes (mRS 0-2 group) and poor clinical outcomes (mRS 3-6 group).

WBV was calculated according to Hct and TP values evaluated at the time of emergency application. The WBV value was calculated using De Simone's formula and blood values at the time of admission (8). The WBV value was calculated separately for both shear rates.

Whole Blood Viscosity Measurement via De Simone's Formula (8).

WBV at HSR $=208 / \mathrm{sec}^{-1}$, and WBW at LSR $=0.5 / \mathrm{sec}^{-1}$ were calculated using $\mathrm{Hct}$ and TP values.

WBV at HSR formula $\left(208 / \mathrm{sec}^{-1}\right):(0.12 \times \mathrm{HCT})+0.17(\mathrm{TP}-$ 2.07)

WBV at LSR formula $\left(0.5 / \mathrm{sec}^{-1}\right):(1.89 \times \mathrm{HcT})+3.76(\mathrm{TP}-$ 78.42)

All data were compared between the two groups. Two different logistic regression models were established for LSR and HSR (Models 1 and 2) to determine the risk factors affecting poor clinical outcomes. Independent risk factors affecting poor clinical outcomes were compared using these models.

\section{Statistical analysis}

All data were analyzed using the Statistical Package for the Social Sciences V23 (SPSS Inc., Chicago, IL, USA) program. The independent samples $t$-test was used to compare normally distributed quantitative data and the Mann-Whitney $U$-test was used to analyze data that did not follow a normal distribution. Categorical data were analyzed using the chi-square test. The individual effects of all variables were examined in a univariate binary logistic regression analysis. Two different logistic regression models were established separately for LSR and HSR; independent risk factors affecting poor clinical outcomes were calculated using multivariate logistic regression analysis, and the comparative results are presented. The cut-off values for LSR and HSR regarding clinical outcome were examined using ROC analysis and area under the curve (AUC), positive-negative predictive value and accuracy values corresponding to each cut-off value are presented. Spearman correlation analysis was performed to examine the correlation between WBV and mRS score. A p-value less than 0.05 is statistically significant.

\section{Results}

Demographic characteristics and clinical outcomes data of the study groups are summarized in Table 1 . Hemoglobin $(13.3 \pm 1.7 \mathrm{~g} / \mathrm{dL}$ vs. $14.4 \pm 1.2 \mathrm{~g} / \mathrm{dL} ; \mathrm{p}=0.002)$, Hct $(38.9 \%$ \pm 3.8 vs. $41.7 \% \pm 3.3 ; p<0.001)$ and TP $(6.8 \pm 1.2 \mathrm{~g} / \mathrm{dL}$ vs. $7.1 \pm 1.4 \mathrm{~g} / \mathrm{L} ; \mathrm{p}=0.013$ ) levels were found to be higher in the In poor clinical outcomes group than the good clinical 
outcomes group. There were no significant difference between the two groups in terms of other demographic characteristics, procedural results and medical history. In addition, there was no significant difference between the two groups in terms of occlusion site, $\mathrm{mTICl}$ score, symptomatic ICH and stroke subtypes ( $p>0.05)$. In poor clinical outcomes group, WBV values were significantly higher compared to the good clinical outcomes group [both HSR (15.9 \pm 0.28 vs. $14.4 \pm 1.216 .4 \pm 0.42 ; p<0.001)$ and LSR $(34.9 \pm 0.2$ vs. $44.9 \pm 3.2 ; p<0.001)]$.

Table 1. Demographic, procedural and medical history data for the study group.

\begin{tabular}{|c|c|c|c|}
\hline Variables & $\begin{array}{r}\mathrm{mRS} 0-2 \\
(n=124)\end{array}$ & $\begin{array}{c}\mathrm{mRS} 3-6 \\
(\mathrm{n}=116)\end{array}$ & p-value \\
\hline Age, years & $68 \pm 7.5$ & $71 \pm 8.5$ & 0.053 \\
\hline Gender, female $n,(\%)$ & $62(50)$ & $6556)$ & 0.805 \\
\hline Hypertension $n,(\%)$ & $98(79)$ & $90(77)$ & 0.204 \\
\hline Diabetes Mellitus n,(\%) & $41(33)$ & $45(38)$ & 0.895 \\
\hline Congestive Heart Failure $\mathrm{n},(\%)$ & $21(16)$ & $19(16)$ & 0.766 \\
\hline Coronary Artery Disease $\mathrm{n},(\%)$ & $53(42)$ & $49(26)$ & 0.255 \\
\hline Atrial Fibrillation $\mathrm{n},(\%)$ & $38(32)$ & $36(31)$ & 0.166 \\
\hline Smoking $n,(\%)$ & $25(20)$ & $24(20)$ & 0.086 \\
\hline NIHSS & $14.5 \pm 0.2$ & $15 \pm 0.3$ & 0.852 \\
\hline Hemoglobin (g/dL) & $13.3 \pm 2.5$ & $14.4 \pm 1.2$ & 0.002 \\
\hline Hematocrit (\%) & $38.9 \pm 3.8$ & $41.7 \pm 3.3$ & $<0.001$ \\
\hline White Blood Cell $\left(10^{3} \mu \mathrm{l}\right)$ & $10.2 \pm 2.3$ & $9.7 \pm 2.3$ & 0.755 \\
\hline Platelet $\left(10^{3} \mu \mathrm{l}\right)$ & $329 \pm 38$ & $332 \pm 41$ & 0.569 \\
\hline Total Protein (g/L) & $6.8 \pm 1.2$ & $7.1 \pm 1.4$ & 0.013 \\
\hline Albumin (g/dL) & $3.5 \pm 0.5$ & $3.4 \pm 0.6$ & 0.067 \\
\hline Total cholesterol, mg/dl & $171 \pm 81.4$ & $169.5 \pm 74.5$ & 0.592 \\
\hline $\mathrm{LDL}-\mathrm{C}, \mathrm{mg} / \mathrm{dl}$ & $104 \pm 31$ & $107 \pm 300$ & 0.064 \\
\hline $\mathrm{HDL}-\mathrm{C}, \mathrm{mg} / \mathrm{dl}$ & $37.7 \pm 11.3$ & $38.3 \pm 11.5$ & 0.112 \\
\hline $\mathrm{TG}, \mathrm{mg} / \mathrm{dl}$ & $148.8 \pm 62.2$ & $138.7 \pm 60.2$ & 0.095 \\
\hline Symptomatic ICH n,(\%) & $7(5)$ & $10(8)$ & 0.308 \\
\hline mTICl score $2 b-3 n,(\%)$ & $101(81)$ & $91(78)$ & 0.326 \\
\hline \multicolumn{4}{|l|}{ Stroke subtype $n,(\%)$} \\
\hline Cardioembolism & $61(49)$ & $61(52)$ & 0.165 \\
\hline Large artery atherosclerosis & $43(35)$ & $40(34)$ & 0.153 \\
\hline Other & $20(16)$ & $15(14)$ & 0.096 \\
\hline \multicolumn{4}{|l|}{ Occlusion site $n,(\%)$} \\
\hline MCA, M1 segment & $66(53)$ & $63(54)$ & 0.103 \\
\hline MCA, M2 segment & $28(23)$ & $23(20)$ & 0.098 \\
\hline$A C A, A 1$ segment & $3(2)$ & $5(4)$ & 0.203 \\
\hline Basiller artery & $7(5)$ & $8(7)$ & 0.156 \\
\hline Internal Carotis Artery & $20(17)$ & $17(15)$ & 0.088 \\
\hline WBV at $\operatorname{LSR}\left(0,5 / \mathrm{s}^{-1}\right)$ & $34.9 \pm 2.2$ & $44.9 \pm 3.2$ & $<0.001$ \\
\hline WBV at HSR $\left(208 / \mathrm{s}^{-1}\right)$ & $15.9 \pm 0.28$ & $16.4 \pm 0.42$ & $<0.011$ \\
\hline
\end{tabular}

NIHSS, National Institutes of Health Stroke Scale; ICH, Intracranial hemorrhage; $\mathrm{mTICI}$, Modified treatment in cerebral ischemia; LDL-C, Low-density lipoprotein cholesterol; HDL-C, High-density lipoprotein cholesterol; TG, Triglycerides; ACA, Anterior cerebral artery MCA, Middle cerebral artery; WBV at HSR, Whole blood viscosity at high shear rate; WBV at LSR, Whole blood viscosity at low shear rate.

In ROC analysis, a cut-off value of 16.1 WBV for HSR had an $76.7 \%$ sensitivity and $76 \%$ specificity for predicting poor clinical outcomes [(AUC): $84.3 \%$, 95\% Cl 72.53-87.25; $\mathrm{p}<0.001$ ] and a cut-off value of 38.5 WBV for LSR had an $75.3 \%$ sensitivity and $78 \%$ specificity for predicting poor clinical outcomes [(AUC: 83.8\%, 95\% Cl 72.4-87.2; $\mathrm{p}<$ 0.001)] (Figure 1).
In univariate and multivariate analyzes, both high LSR at WBV (OR: 2.679, $\mathrm{p}<0.001$ ) and high HSR at WBV (OR: $1.278, p<0.001)$ were independent predictors for the poor clinical outcomes (Table 2).

There was a significant positive correlation between LSR at WBV and mRS score $(0-6)(r=0.457, p<0.001)$ and HSR at WBV and mRS score $(0-6)(r=0.427, p<0.001)$ (Figure $2 A-B$, respectively).

Table 2. The effects of variables on poor outcomes in logistic regression analysis

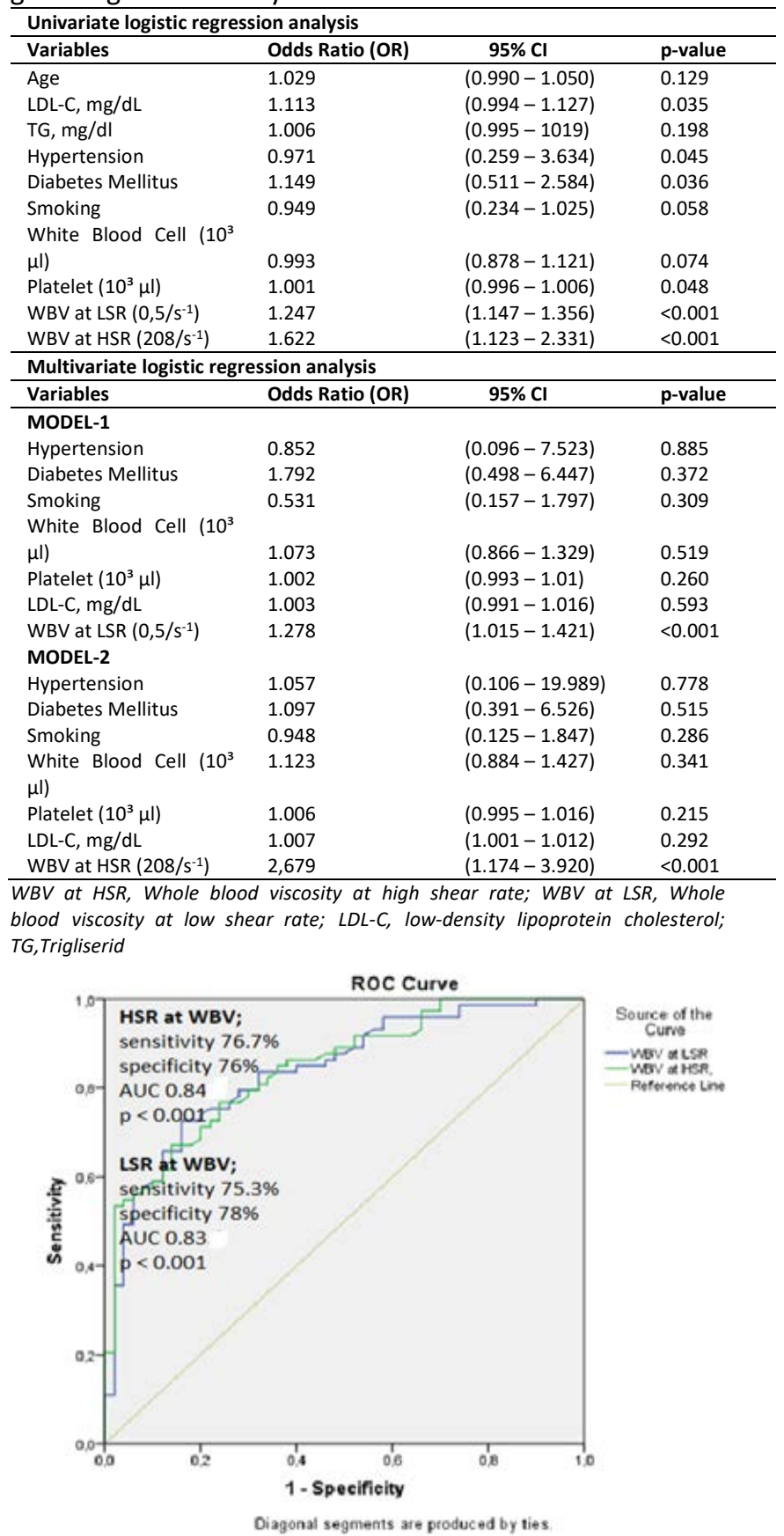

Fig 1. ROC curve analysis showing the predictive cut-off value of WBV at a high shear rate (blue line) and low shear rate (green line) for poor clinical outcomes. AUC, area under the curve; HSR, high shear rate; LSR, low shear rate; ROC, receiver operating characteristic; $W B V$, whole blood viscosity. 

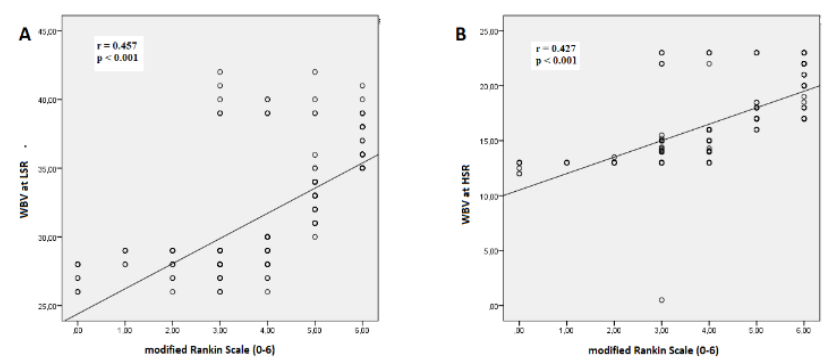

Fig 2. (A) Correlation between WBV at LSR and mRS score, (B) Correlation between WBV at HSR and $m R S$ score

\section{Discussion}

Our study is the first to evaluate the relationship between WBV and functional status (evaluated after 90 days) in patients treated with MT. The results of this study demonstrate that the increased WBV values at LSR and HSR were an independent risk factor for poor clinical outcomes in Ais patients treated with MT. Besides, increased WBV values both at LSR and HSR were positively correlated with higher $\mathrm{mRS}$ score.

BV is determined by blood components and varies with the shear rate as a non-Newtonian fluid $(1,9)$. Blood viscosity is affected by many rheologic components. Blood cells and plasma components are closely related to BV. As a result of increased BV, blood flow rate decreases and stasis occurs. Besides, changes in BV may effect the endothelial shear stress, an important component of atherosclerosis, and therefore trigger the development of atherosclerosis (9-11). The complex effects of BV accelerate the atherothrombotic process and development of cardiovascular diseases and may also effect the prognosis of these diseases (11). Lowe et al. demonstrated that BV is a risk factor similar to diastolic blood pressure, low-density lipoprotein cholesterol, and smoking in patients with stroke and myocardial infarction (12). Resch et al. reported that high BV is associated with death due to recurrent stroke, myocardial infarction, and cardiovascular disease (13). But, in routine clinical practice, evaluation of WBV with viscometer is limited owing to the necessity of technical equipment and lack of standardization in its assessment. De Simone et al. offered that WBV can be extrapolated from its primary constituents including hematocrit and total plasma protein at the desired shear rate with a simple formula. The different shear rates used when calculating WBV are indicators of different hemodynamic settings. LSR reflects the low velocity blood flow at the end of diastole and HSR reflects the high velocity blood flow at the systolic peak in the major arteries. The accuracy of this formula has been supported in large patient populations and in validation analyses performed with a viscometer device, which measures blood viscosity (8). This De Simone formula has been used in many different cardiovascular patient populations (14-16). Some recent studies have explored the relationship between acute stroke and blood viscosity: Furukawa et al. and Song et al. observed increased blood viscosity in stroke patients with small artery occlusion $(17,18)$; Fisher et al. demonstrated that increased BV is associated with cerebral ischemia (19); and Li et al. found that increased BV in patients with low shear stress is associated with silent cerebral ischemia (20). This close relationship between increased BV and cerebral ischemia may affect the clinical outcomes of the AIS patients as demonstrated in our study.

MT with stent-retrievers results in higher recanalization rates. In the study of Nogueira et al., Despite successful recanalization rates, good clinical results evaluated with the $\mathrm{mRS}$ score $\leq 2$ were obtained in only half of the patients (21). Some authors have identified a lot of clinic factors that influence poor outcomes in patients with AIS treated with $\mathrm{MT}(22,23)$. In some studies, the association of laboratory parameters with poor functional results was evaluated $(24,265)$. Wang et al described the PREDICT scale after successful MT for poor outcomes for early prediction (26). Given the relationship between BV and ischemic cerebrovascular events, increased WBV induced endothelial dysfunction, peripheral vascular resistance, thrombosis, stasis, and impaired collateral flow can lead to increased neuronal ischemia at the micro and macrovascular level. These changes may affect functional outcomes negatively despite successful recanalization with MT in AIS patients. In our study, for the first time in literature, we evaluated the relationship between long-term outcomes of AIS patients undergoing MT and WBV calculated using De Simone formula. Herein, it was shown that increased blood viscosity was an independent predictor of poor functional outcomes. Also, the fact that the increased WBV value correlated positively with the increased $\mathrm{mRS}$ score supports this relationship. Considering the results of our study, clinicians may use WBV, a practical, easy and inexpensive parameter, as a predictor of long-term outcomes during the early evaluation of patients undergoing endovascular treatment for AIS. Accordingly, blood viscosity may also be included as one of the variables in the scoring tools designed to predict post-MT clinical outcomes.

\section{Limitations}

Our study has several limitations. Sample size, retrospective analysis of prospectively collected data, non-randomized and single-center study are important methodological shortcomings. The possibility of an unknown confounding factor affecting the results cannot be ruled out completely. The calculated WBV value has not been verified using a viscometer. The extrapolation formula that we used in our study has been validated and utilized in several other studies but direct comparison of estimated and directly measured WBV in this patient population may strengthen our results and serve precision. In addition, other hemorheological factors that may affect BV such as erythrocyte aggregability and rigidity were not evaluated.

\section{Conclusion}

This study demonstrates for the first time in the literature 
that the increased WBV is an independent risk factor and correlated with poor clinical outcomes in AIS patients treated with $\mathrm{MT}$. BV may be added to the scoring systems which predict the long-term outcomes in these patients if our results are confirmed with large scale, prospective studies.

Ethical Approval: Ethics Committee of University of Health Sciences, Training and Research Hospital (TUEK1-2019 BADK / 1-5). Author Contributions:

Concept: M.Y.,C.K.A.,E.G.

Literature Review: M.Y.

Design : M.Y.,C.K.A.,E.G.

Data acquisition: M.Y.

Data analysis and interpretation: Ç.K.A,E.G.,M.Y.,U.A.

Writing manuscript: M.Y., C.K.A.

Critical revision of manuscript: C..K.A.,E.G.,U.A.

Conflict of Interest: Authors declared no conflict of interest.

Financial Disclosure: Authors declared no financial support.

\section{References}

1. Daniel J. Cho. Blood Viscosity Abnormalities in Large and Small Vessel Diseases: Future Directions for Plasma Medicine. Plasma Medicine 2012; 2: 221-235

2. Ott EO, Lechner $\mathrm{H}$, Aranibar A. High blood viscosity syndrome in cerebral infarction. Stroke 1974;5:330-333.

3. Fisher M, Meiselman HJ. Hemorheological factors in cerebral ischemia. Stroke 1991;22:1164-1169.

4. Grotemeyer KC, Kaiser R, Grotemeyer KH, Husstedt IW. Association of elevated plasma viscosity with small vessel occlusion in ischemic cerebral disease. Thromb Res 2014; 133: 96-100.

5. Powers WJ, Derdeyn CP, Biller J, Coffey CS, Hoh BL, Jauch EC, et al. 2015 American Heart Association/American Stroke Association Focused Update of the 2013 Guidelines for the early management of patients with acute ischemic stroke regarding endovascular treatment: a guideline for healthcare professionals from the American Heart Association/American Stroke Association. Stroke 2015 ; 46:302035.

6. Nogueira RG, Liebeskind DS, Sung G, Duckwiler G, Smith WS. Predictors of good clinical outcomes, mortality, and successful revascularization in patients with acute ischemic stroke undergoing thrombectomy: pooled analysis of the Mechanical Embolus Removal in Cerebral Ischemia (MERCI) and Multi MERCI Trials. Stroke 2009 ; 40:3777-83.

7. Rankin J. Cerebral vascular accidents in patients over the age of 60: II. Prognosis. Scottish Medical Journal. 1957 ; 2:200-215.

8. de Simone G, Devereux RB, Chien S, Alderman MH, Atlas SA, Laragh $\mathrm{JH}$. Relation of blood viscosity to demographic and physiologic variables and to cardiovascular risk factors in apparently normal adults. Circulation 1990; 81: 107-117.

9. Chatzizisis YS, Coskun AU, Jonas M, Edelman ER, Feldman $\mathrm{CL}$, Stone $\mathrm{P}$, et al. Role of endothelial shear stress in the natural history of coronary atherosclerosis and vascular remodeling: molecular, cellular, and vascular behavior. J Am Coll Cardiol. 2007; 49: 2379-93.

10. Wu KK. Laboratory studies in arterial thromboembolism. In: Koepke JA, ed. Practical Laboratory Hematology. 2nd ed. New York: Churchill Livingstone; 1991. p.445- 67.

11. Celik T, Balta S, Ozturk C, Iyisoy A. Whole Blood Viscosity and Cardiovascular Diseases: A Forgotten Old Player of the Game. Med Princ Pract. 2016;25:499-500.

12. Lowe GD, Lee AJ, Rumley A, Price JF, Fowkes FG. Blood viscosity and risk of cardiovascular events: the Edinburgh Artery Study. Br J Haematol. 1997 ;9: 168-73.

13. Resch KL, Ernst E, Matrai $A$, Paulsen HF. Fibrinogen and viscosity as risk factors for subsequent cardiovascularevents in stroke survivors. Ann Intern Med 1992; 117: 371375.

14. Cetin EH, Cetin MS, Canpolat U, Aydin S, Aras D, Topaloglu $S$, et al. Prognostic significance of whole blood viscosity estimated by de Simone's formula in ST-elevation myocardial infarction. Biomark Med 2016; 10: 495-511.

15. Çekici Y, Kılıç S, Saraçoğlu E, Çetin M, Veysel Düzen I, Yılmaz $M$. The relationship between blood viscosity and Isolated Coronary Artery Ectasia. Acta Cardiol Sin. 2019;35:20-26.

16. Erdogan G, Yenercag M, Arslan U. The Relationship between Blood Viscosity and Acute Arterial Occlusion. Journal of Cardiovascular Emergencies. 2020;6:7-12

17. Song SH, Kim JH, Lee JH, Yun YM, Choi DH, Kim HY. Elevated blood viscosity is associated with cerebral small vessel disease in patients with acute ischemic stroke. BMC Neurology. 2017;17:20.

18. Furukawa $K$, Abumiya $T$, Sakai $K$, Hirano $M$, Osanai $T$, Shichinohe $\mathrm{H}$, et al. Increased Blood Viscosity in Ischemic Stroke Patients with Small Artery Occlusion Measured by an Electromagnetic Spinning Sphere Viscometer. J Stroke Cerebrovasc Dis. 2016;25:2762-2769.

19. Fisher M, Meiselman HJ. Hemorheological factors in cerebral ischemia. Stroke 1991; 22: 1164-1169.

20. Li RY, Cao ZG, Li Y, Wang RT. Increased whole blood viscosity is associated with silent cerebral infarction. Clin Hemorheol Microcirc 2015; 59: 301-307

21. Nogueira RG, Smith WS; MERCI and Multi MERCI Writing Committee. Safety and efficacy of endovascular thrombectomy in patients with abnormal hemostasis: pooled analysis of the MERCI and multi MERCI trials. Stroke 2009;40:51622.

22. Linfante I, Starosciak AK, Walker GR, Dabus G, Castonguay AC, Gupta R5, et al. Predictors of poor outcome despite recanalization: a multiple regression analysis of the NASA registry.J Neurointerv Surg. 2016;8:224-9.

23. Tonetti DA, Desai SM, Casillo S, Stone J, Brown M, Jankowitz $B$, et al. Successful reperfusion, rather than number of passes, predicts clinical outcome after mechanical thrombectomy. J Neurointerv Surg. 2019-015330.

24. Gordon WR, Salamo RM, Behera A, Chibnall J, Alshekhlee A, Callison RC, et al. Association of blood glucose and clinical outcome after mechanical thrombectomy for acute ischemicstroke. Interv Neurol 2018; 7: 182-188.

25. Goyal N, Tsivgoulis G, Chang JJ, Malhotra K, Pandhi A, Ishfaq $M F$, et al. Neutrophil-to-lymphocyte ratio as a prognostic biomarker of outcomes in large vessel occlusion strokes. Stroke 2018; 49: 1985-1987.

26. Wang $H$, Zhang $M$, Hao $Y$, Zi W, Yang D, Zhou Z, et al. Early Prediction of Poor Outcome Despite Successful Recanalization After Endovascular Treatment for Anterior Large Vessel Occlusion Stroke. World Neurosurg. 2018; 115:e312-e32 